\title{
MARKET BASKET ANALYSIS PADA PERUSAHAAN RETAIL MENGGUNAKAN ALGORITMA APRIORI DAN SALES FORECASTING
}

(Market Basket Analysis in Retail Company Using Apriori Algorithm

\author{
and Sales Forecasting)
}

\author{
Nursanti Irliana, Vensy Vydia \\ Program Studi Sistem Informasi, Jurusan Teknologi Informasi \\ Fakultas Teknologi Informasi dan Komunikasi, Universitas Semarang \\ Email: santi@usm.ac.id, vensy@usm.ac.id
}

\begin{abstract}
A retail company usually has time services system or spesific discount time to attract customers. One of this time service is weekend sales promotion, which the retail gives a specific discount rate for some products those are needed by a specific customer type. The products selected for this promotion must be right, appropriate with the customers needs and they are selected through a calculation based on right trend and sales forecasting. The products which will be promoted should be selected based on the method that describes the most wanted items based on sales trend. Inline with this condition, Apriori algorithm is chosen to apply the calculation. And after the products are selected, the sales forecasting can be done by observing the sales trend, profit trend, and sales planning.
\end{abstract}

Keyword : Apriori Algorithm, Sales Forecasting, Product Selection

\section{PENDAHULUAN}

Sebuah perusahaan retail yang telah menentukan segmen mana yang menjadi target pasar mereka, perlu menentukan bagaimana melayani dan memasuki pasar yang dituju dengan program pemasarannya. Untuk hal ini, perusahaan retail membutuhkan teknik positioning yang tepat. Positioning , menurut Hendri Ma'aruf (2005) adalah membentuk citra perusahaan atau produk di mata masyarakat. Positioning berkenaan dengan menempatkan posisi perusahaan di benak masyarakat atau calon pembeli. Positioning bukanlah sekedar program iklan, melainkan totalitas program pemasaran yang mencakup kegiatan pemasaran mulai dari produk, harga, merchandising, staf pelayanan yang diperlukan dan lain-lainnya dalam upaya pembentukan citra yang dimaksud. Positioning berkenaan dengan value proposition, yaitu suatu nilai yang ditawarkan kepada masyarakat pembelinya. Misalnya, dalam perusahaan retail yang menjual barang - barang fresh food atau makanan segar seperti sayur,daging atau ikan, akan ada nilainya jika memberikan citra "murah - meriah" di waktu-waktu tertentu dimana end user (pembeli akhir, kategori rumah tangga) mempunyai waktu untuk berbelanja.

Konsumen tipe end user biasanya akan mengunjungi perusahaan ritel (swalayan) di hari Sabtu dan untuk berbelanja kebutuhan rumah tangga. Biasanya mereka akan berbelanja dalam jumlah tertentu yang cukup untuk memenuhi kebutuhan satu bulan atau satu minggu. Oleh karena itu, perusahaan ritel sebaiknya memiliki program khusus agar menarik konsumen datang berbelanja di hari Sabtu - Minggu. 
Untuk dapat melaksanakan promosi khusus Sabtu-Minggu ini, perusahaan retail perlu perencanaan merchandise. Yaitu sebuah kegiatan pengadaan barang-barang yang sesuai dengan bisnis yang dijalani untuk dijual kepada konsumen. Tentunya dalam merencanakan merchandise ada hal- hal yang harus dipertimbangkan yang menyangkut peramalan , inovasi, assortment (ragam produk yang ditentukan berasaran metede tertentu), merk timing dan alokasi. Jika digambarkan,maka aspekaspek itu akan seperti Gambar 1 berikut ini :

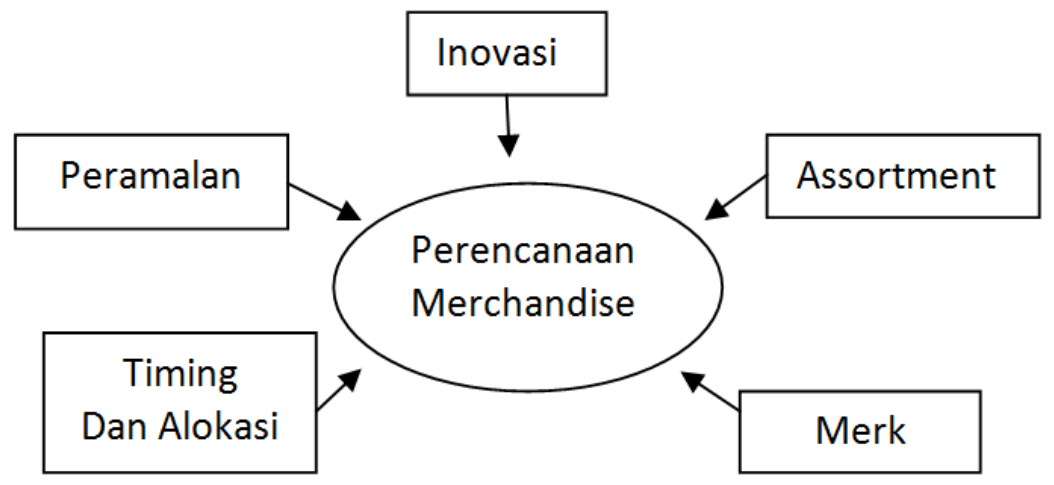

Gambar 1. Aspek-aspek Perencanaan Merchandise

Dalam hal penentuan assortment, ada dua hal yang harus diperhatikan, yaitu :

a. Wide/lebar, yaitu banyaknya variasi kategori produk yang dijual. Dikatakan "lebar" jika ragam kategori produknya banyak. Dan "sempit" jika ragam kategori produknya sedikit.

b. Deep/dalam, yaitu banyaknya item pilihan dalam masing-masing kategori produk. Dikatakan "dalam", jika banyak pilihan (warna,ukuran,bahan) dalam setiap kategori produk. Dikatakan "dangkal" jika sedikit pilihan dalam setiap kategori produk.

Jika sebuah perusahaan ritel ingin mengadakan promosi penjualan di SabtuMinggu, maka sebaiknya menganut konsep Narrow and Deep, yaitu sedikit ragam kategori produk dan masing-masing banyak pilihan. Berikut keuntungan dan kerugian dalam konsep Narrow and Deep ini, menurut Hendri Ma'aruf (2005) :

Tabel 1. Keuntungan dan Kerugian Konsep Narrow and Deep dalam Perencanaan Merchandise

\begin{tabular}{|c|c|}
\hline KEUNTUNGAN & KERUGIAN \\
\hline $\begin{array}{c}\text { Citra sebagai gerai khusus segmen atau } \\
\text { produk tertentu }\end{array}$ & $\begin{array}{l}\text { Bukan sebagai gerai one stop shopping jika } \\
\text { produk lain tidak mengikuti kebutuhan } \\
\text { konsumen (harga, ketersediaan) }\end{array}$ \\
\hline $\begin{array}{c}\text { Pilihan banyak dalam kategori-kategori } \\
\text { yang dijual }\end{array}$ & $\begin{array}{l}\text { Rawan terhadap perubahan trend dan } \\
\text { seasonal sales }\end{array}$ \\
\hline $\begin{array}{l}\text { Staf yang teampil dalam kategori produk } \\
\text { yang dijual }\end{array}$ & $\begin{array}{l}\text { Perlu upaya untuk memperluas cakupan } \\
\text { penjualan }\end{array}$ \\
\hline
\end{tabular}


Untuk mengimplementasikan konsep Narrow and Deep ini dalam promosi Sabtu Minggu, maka harus diketahui terlebih dahulu informasi mengenai barang apa saja yang dibeli oleh konsumen, mengikuti trend dalam kurun waktu tertentu. Informasi ini paling mudah dilihat dari data internal perusahaan. Data internal memuat belanja konsumen setiap Sabtu - Minggu, katakanlah dalam periode 3 minggu terakhir oleh konsumen bertipe end user. Produk apa saja yang dibeli dan berapa jumlah yang dibeli. Jika produk yang akan dipromosikan direncanakan lebih dari satu produk, maka harus diamati dan dianalisa, produk ap a saja yang biasa dibeli konsumen dalam kurun waktu tervsebut.

Informasi ini dapat diperoleh dari catatan Gate Perfomance Analysis atau arus lalu lintas orang yang bertransaksi di kasir. Data yang diambil adalah catatan transaksi pembelian produk Fresh Food di hari Sabtu - Minggu, di jam awal buka toko sampai 8 jam kedepan. Asumsi adalah produk Fresh Food akan tetap segar maksimal 8 jam setelah didisplay. Adapun data yang harus diperhatikan mencakup :

a. Bauran produk yang dibeli di tiap transaksi

b. Jumlah atau quantity produk yang dibeli di tiap transaksi

Dari data di atas, kemudian dilakukan pengurutan atas jumlah atau quantity yang dibeli. Kemudian dari data yang telah urut, diambil beberapa data teratas atau jumlah pembelian terbanyak ,misalnya top 30. Lalu diamati bauran produk yang dibeli. Ini akan menggambarkan pola kebutuhan konsumen end use akan produk Fresh Food yang dibutuhkan.

Setelah mendapatkan informasi mengenai bauran produk yang dibeli konsumen, harus dikerucutkan lagi dan dipilih beberapa produk saja yang memang akan dipromosikan. Karena biasanya tidak semua produk dipilih untuk diberikan harga khusus. Untuk dapat menentukan pilihan, maka diperlukan sebuah aturan asosiasi. Algoritma Apriori termasuk jenis aturan asosiasi pada Data Mining. Data Mining , menurut Kusrini ( 2009) adalah proses yang menggunakan teknik statistic,matematika, kecerdasan buatan dan machine learning untuk mengidentifikasi informasi yang bermanfaat dan pengetahuan yang terakit dari berbagai database. Algoritma ini ditujukan untuk mencari kombinasi item-set yang mempunyai suatu nilai keseringan tertentu sesuai kriteria atau filter yang diinginkan. Hasil dari algoritma ini dapat digunakan untuk membantu dalam pengambilan keputusan pihak manajemen.

Setelah produk yang akan dipromokan selesai dianalisa dan dipilih, maka berikutnya perusahaan retail harus menentukan jumlah atau quantity yang akan diorder untuk disediakan dalam display. Jumlah barang ini terkait dengan sales trend atau tren penjualan dalam kurun waktu tertentu. Kemudian diambil rata-rata per periodenya. Sebagai contoh adalah dalam Tabel 2 berikut :

Tabel 2 llustrasi Sales Trend

\begin{tabular}{|c|c|c|c|c|}
\hline Barang & $\begin{array}{c}\text { Minggu 1 } \\
\text { (M1) }\end{array}$ & $\begin{array}{c}\text { Minggu 2 } \\
\text { (M2) }\end{array}$ & $\begin{array}{c}\text { Minggu 3 } \\
\text { (M3) }\end{array}$ & $\begin{array}{c}\text { Rata-rata /minggu } \\
\text { (M1+M2+M3) }\end{array}$ \\
\hline A & 10 & 20 & 30 & 3 \\
\hline$B$ & 5 & 10 & 6 & 20 \\
\hline
\end{tabular}

Setelah mengetahui rata rata per minggunya, maka dibuatlah prakiraan penjualannya atau sales forecasting. Misalnya ingin menaikkan penjualan 
Tabel 3. Ilustrasi Sales Forecasting

\begin{tabular}{|c|c|c|}
\hline Barang & $\begin{array}{c}\text { Rata-rata } \\
\text { Penjualan } \\
\text { (S) }\end{array}$ & $\begin{array}{c}\text { Sales Forecast } \\
(\mathbf{2 0} \% \mathbf{x} \mathbf{S})+\mathbf{S}\end{array}$ \\
\hline A & 20 & 24 \\
\hline B & 7 & 8,4 \\
\hline
\end{tabular}

\section{METODE}

Penelitian ini menggunakan metodologi Cross_industry Standard Process for Data Mining (CRISP-DM). Menurut Kusrini
(2009), dalam CRISP-DM,sebuah proyek data mining memiliki siklus hidup yang terbagi dalam enam fase. Siklus ini dapat digambarkan dalam Gambar 2 berikut ini :

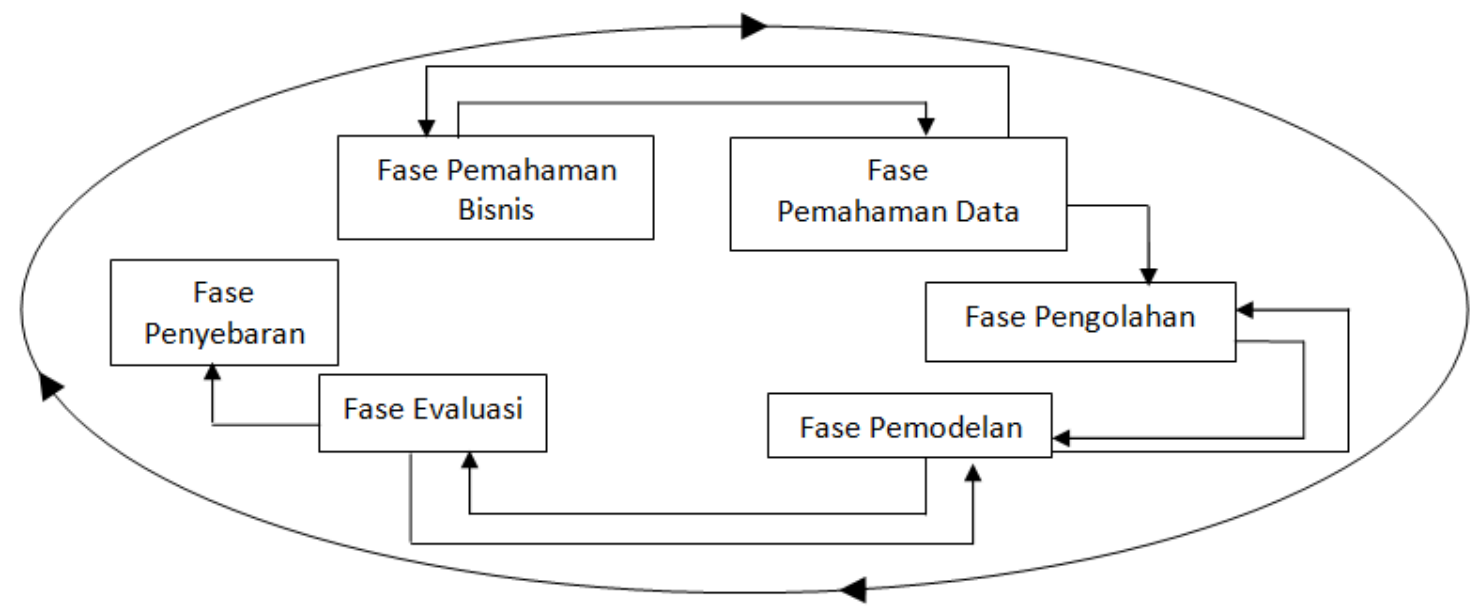

Gambar 2. Proses Data Mining menurut CRISP-DM

Keseluruhan fase berurutan yang ada tersebut bersifat adaptif. Fase berikutnya dalam urutan bergantung pada keluaran dari fase sebelumnya. Hutbungan penting antar fase digambarkan dengan panah. Sebagai contoh, jika proses berada pada pemodelan, proses mungkin harus kembali kepada fase pengolahan untuk perbaikan atau berpindah maju kepada fase evaluasi.

Dalam penelitian ini, keenam fase ini dapat dijelaskan sebagai berikut :

1. Fase Pemahaman Bisnis

a. Dimulai dengan menentukan tujuan proyek, yaitu memilih bauran produk yang akan disiapkan guna promosi Fresh Food khusus Sabtu - Minggu untuk konsumen bertipe end user. b. Misal nantinya akan berkonsentrasi pada produk ayam, daging, tomat, cabe merah, dan telur. Maka tahap berikutnya harus berkonsentrasi pada data transaksi yang mengandung kelima item produk tersebut.

c. Tujuan di atas kemudian diterjemahkan menjadi formula dari permasalahan data mining. Bahwa untuk memilih bauran produk yang tepat, diperlukan penggalian informasi relevan dengan sales trend dari gate performance analysis.

d. Menyiapkan strategi awal untuk mencapai tujuan di atas, yaitu menggunakan algoritma Apriori 
untuk pembentukan model asosiasi.

2. Fase Pemahaman Data

a. Mengumpulan data transaksi konsumen bertipe end user selama kurun 3 minggu terakhir sebelum perencanaan promosi dilakukan.

b. Kemudian diambil data konsumen yang di dalam transaksinya terdapat produk Fresh Food seperti dalam poin $1 \mathrm{~b}$.

c. Berikutnya, diambil data pembelanjaan terbesar, yaitu misal top 20.

3. Fase Pengolahan Data

a. Setelah data awal siap, maka diolah lebih lanjut dengan membentuk ke dalam table belanja konsumen

b. Lalu dilanjutkan dengan mengolah data sales trend, profit trend, pricing untuk menentukan jumlah yang harus diorder per produk dan berapaharganya. Tentunya juga harus memperhatikan forecasting, sesuai dengan perencanaan penjualan.

4. Fase Pemodelan

a. Dalam tahapan ini, dilakukan pembuatan model. Bisa menggunakan software bantu apa saja, termasuk Microsoft Excel.

b. Dalam penelitian ini, pengelompokan data mining yang dipilih adalah asosiasi, dengan algortima Apriori.

c. Perhitungan dilakukan tahap demi tahap mengikuti aturan dalam algoritma Apriori.nd,

d. Dan setelah menganalisis sales trend, maka diperoleh rata-rata penjualan masing-masing produk per transaksi

e. Kemudian dari rencana penjualan, dapat diperoleh angka prakiraan penjualan atau sales forecasting.

f. Harga per produk ditentukan dengan melihat harga normal saat

5. Fase Evaluasi

ini, harga beli , harga pasar , profit trend dan profit yang ingin dicapai dalam promosi.

a. Setelah model dibuat, kemudian dilakukan evaluasi apakah telah sah memang telah sesuai dengan tujuan awal yaitu menentukan produk yang akan dipromosikan di Sabtu - Minggu .

b. Kemudian akan terbentuk sebuah informasi penting sesuai dengan tujuan awal.

6. Fase Penyebaran

a. Laporan jadi kemudian diberikan kepada pihak yang berwenang dalam penentuan promosi ini.

Data Mining ,menurut Kusrini (2009) , dibagi menjadi beberapa kelompok. Salah satunya adalah Asosiasi, yang digunakan dalam penelitian ini. Tugas Asosiasi dalam data mining adalah menemukan atribut yang muncul dalam satu waktu.

Association rule (aturan asosiatif) akan menemukan pola tertentu yang mengasosiasikan data yang satu dengan data yang lain. Untuk mencari association rule dari suatu kumpulan data, tahap pertama yang harus dilakukan adalah mencari frequent itemset terlebih dahulu. Frequent itemset adalah sekumpulan item yang sering muncul secara bersamaan. Setelah semua pola frequent itemset ditemukan, barulah mencari aturan asosiatif atau aturan keterkaitan yang memenuhi syarat yang telah ditentukan.

Jika diasumsikan bahwa barang yang dijual di swalayan adalah semesta, maka setiap barang akan memiliki variabel yang akan menunjukkan keberadaannya atau tidak barang tersebut dalam satu transaksi atau satu keranjang belanja. Pola yang didapat dugunakan untuk menganalisa barang yang sering dibeli secara bersamaan. Pola tersebut dapat dirumuskan dalam sebuah association rule. Sebagai contoh konsumen biasanya akan membeli 
kopi dan susu yang ditunjukkan sebagai berikut :

Kopi $\rightarrow$ susu[support $=2 \%$,confidence $=60 \%$ ]

Association rule diperlukan suatu variable ukuran yang ditentukan sendiri oleh user untuk menentukan batasan sejauh mana atau sebanyak apa output yang diinginkan user.

Support dan confidence adalah sebuah ukuran kepercayaan dan kegunaan suatu pola yang telah ditemukan. Nilai support $2 \%$ menunjukkan bahwa keseluruhan dari total transaksi konsumen membeli kopi dan susu secara bersamaan yaitu sebanyak $2 \%$. Sedangkan confidence $60 \%$ yaitu menunjukkan bila konsumen membeli kopi dan pasti membeli susu sebesar $60 \%$.

Algoritma Apriori adalah salah satu algoritma yang melakukan pencarian frequent itemset dengan menggunakan teknik association rule. Algoritma Apriori menggunakan pengetahuan frekuensi atribut yang telah diketahui sebelumnya untuk memproses informasi selanjutnya. Pada algoritma Apriori menentukan kandidat yang mungkin muncul dengan cara memperhatikan minimum support dan minimum confidence. Support adalah nilai pengunjung atau persentase kombinasi sebuah item dalam database. Rumus support adalah sebagai berikut :

$\operatorname{Support}(A)=$

$\frac{\text { Jml transaksi mengandung } A}{\text { Total transaksi }} \times 100 \%$

Sedangkan confidence adalah nilai kepastian yaitu kuatnya hubungan antar item dalam sebuah Apriori. Confidence dapat dicari setelah pola frekuensi munculnya sebuah item ditemukan. Rumus untuk menghitung confidence adalah sebagai berikut :

Contoh misalnya ditemukan aturan $A \rightarrow B$ maka:

Confidence $\mathrm{P}(\mathrm{B} \mid \mathrm{A})=$

$\frac{\text { Total transaksi mengandung A dan B }}{\text { Transaksi mengandung A }} \times 100 \%$

Proses utama yang dilakukan dalam algoritma Apriori untuk mendapat frequent itemset yaitu:

1. Join (penggabungan)

Proses ini dilakukan dengan cara pengkombinasian item dengan item yang lainnya hingga tidak dapat terbentuk kombinasi lagi.

2. Prune (pemangkasan)

Proses pemangkasan yaitu hasil dari item yang telah dikombinasikan kemudian dipangkas dengan menggunakan minimum support yang telah ditentukan oleh user.

Prinsip dari Algoritma Apriori antara lain :

1. Mengumpulkan item yang tunggal kemudian mencari item yang terbesar.

2. Dapatkan candidate pairs kemudian hitung large pairs dari masing-masing item.

3. Temukan candidate triplets dari setiap item dan seterusnya.

4. Setiap subset dari sebuah frequent itemset harus menjadi frequent.

\section{PEMBAHASAN}

Data transaksi dalam kurun tiga minggu terakhir atas belanja konsumen tipe end auser, yang mengandung produk - produk yang akan dipromosikan adalah seperti dalam Tabel 4 berikut ini: 
Tabel 4. Data Top 20 Transaksi

\begin{tabular}{|c|c|c|c|}
\hline Transaksi & Produk & Transaksi & Produk \\
\hline 1 & A, C, D,E & 11 & A, B, E \\
\hline 2 & B, C, D, E & 12 & A, C \\
\hline 3 & B, C, D & 13 & A, C, E \\
\hline 4 & A, E & 14 & B, D, E \\
\hline 5 & B, C, D & 15 & A, B, D \\
\hline 6 & A, D, E & 16 & C, E \\
\hline 7 & B, D & 17 & A, B, D, E \\
\hline 8 & B, C & 18 & D, E \\
\hline 9 & B, E & 19 & A, D, C \\
\hline 10 & A, B, C & 20 & A, B, C, D \\
\hline
\end{tabular}

Keterangan:

$\mathrm{A}=$ Ayam; $\mathrm{B}=$ Daging; $\mathrm{C}=$ Tomat; $\mathrm{D}=$ Cabe Merah; $\mathrm{E}=$ Telur

Data dalam tabel transaksi di atas kemudian dibuat dalam bentuk tabular sebagaimana dalam Tabel 5 dibawah ini :

Tabel 5. Format Tabular Data Transaksi

\begin{tabular}{|c|c|c|c|c|c|}
\hline Transaksi & Ayam $(\mathbf{A})$ & Daging (B) & Tomat (C) & Cabe Merah (D) & Telur (E) \\
\hline 1 & 1 & 0 & 1 & 1 & 1 \\
\hline 2 & 0 & 1 & 1 & 1 & 1 \\
\hline 3 & 0 & 1 & 1 & 1 & 0 \\
\hline 4 & 1 & 0 & 0 & 0 & 1 \\
\hline 5 & 0 & 1 & 1 & 1 & 0 \\
\hline 6 & 1 & 0 & 0 & 1 & 1 \\
\hline 7 & 0 & 1 & 0 & 1 & 0 \\
\hline 8 & 0 & 1 & 1 & 0 & 0 \\
\hline 9 & 0 & 1 & 0 & 0 & 1 \\
\hline 10 & 1 & 1 & 1 & 0 & 0 \\
\hline 11 & 1 & 1 & 0 & 0 & 1 \\
\hline 12 & 1 & 0 & 1 & 0 & 0 \\
\hline 13 & 1 & 0 & 1 & 0 & 1 \\
\hline 14 & 0 & 1 & 0 & 1 & 1 \\
\hline 15 & 1 & 1 & 0 & 1 & 0 \\
\hline 16 & 0 & 0 & 1 & 0 & 1 \\
\hline 17 & 1 & 1 & 0 & 1 & 1 \\
\hline 18 & 0 & 0 & 0 & 1 & 1 \\
\hline 19 & 1 & 0 & 0 & 1 & 1 \\
\hline 20 & 1 & 1 & 1 & 1 & 0 \\
\hline
\end{tabular}

Berikutnya adalah membuat kombinasi 2 itemset pada setiap transaksi dan frekuensi masin-masing kombinasi dihitung sesuai dengan data tabular pada Tabel 5. Pola kombinasi yang didapatkan dapat dilihat pada Tabel 6. Dan dihitung pula support dan confidencenya. 
Tabel 6. Pola Kombinasi 2 itemset

\begin{tabular}{|c|c|c|c|c|c|}
\hline Pola Kombinasi 2 itemset & Jumlah & \multicolumn{2}{|c|}{ Support } & \multicolumn{2}{c|}{ Confidence } \\
\hline Jika membeli Ayam, akan membeli Daging & 2 & $2 / 20$ & $10 \%$ & $2 / 11$ & $18.2 \%$ \\
\hline Jika membeli Ayam, akan membeli Tomat & 4 & $4 / 20$ & $20 \%$ & $4 / 11$ & $36.3 \%$ \\
\hline Jika membeli Ayam, akan membeli Cabe Merah & 2 & $2 / 20$ & $10 \%$ & $2 / 11$ & $18.2 \%$ \\
\hline Jika membeli Ayam, akan membeli Telur & 5 & $5 / 20$ & $25 \%$ & $5 / 11$ & $45.5 \%$ \\
\hline Jika membeli Daging, akan membeli Tomat & 5 & $5 / 20$ & $25 \%$ & $5 / 12$ & $41.7 \%$ \\
\hline Jika membeli Daging, akan membeli Cabe Merah & 4 & $4 / 20$ & $20 \%$ & $4 / 12$ & $33.3 \%$ \\
\hline Jlka membeli Daging, akan membeli Telur & 3 & $3 / 20$ & $15 \%$ & $3 / 12$ & $25 \%$ \\
\hline Jlka membeli Tomat, akan membeli Cabe Merah & 4 & $4 / 20$ & $20 \%$ & $4 / 10$ & $40 \%$ \\
\hline Jlka membeli Tomat, akan membeli Telur & 3 & $3 / 20$ & $15 \%$ & $3 / 10$ & $30 \%$ \\
\hline Jlka membeli Cabe Merah, akan membeli Telur & 3 & $3 / 20$ & $15 \%$ & $3 / 12$ & $25 \%$ \\
\hline
\end{tabular}

Lalu dibuatlah kombinasi 3 itemset berikut hitungan support dan confidencenya seperti dalam Tabel7.

Tabel 7. Pola Kombinasi 3 item set

\begin{tabular}{|c|c|c|c|c|c|}
\hline Pola Kombinasi 3 itemset & Jumlah & \multicolumn{2}{|c|}{ Support } & \multicolumn{2}{|c|}{ Confidence } \\
\hline $\begin{array}{c}\text { Jika membeli Ayam dan Daging, akan membeli } \\
\text { Tomat }\end{array}$ & 2 & $2 / 20$ & $10 \%$ & $2 / 5$ & $40 \%$ \\
\hline $\begin{array}{l}\text { Jlka membeli Ayam dan Daging, akan membeli Cabe } \\
\text { Merah }\end{array}$ & 2 & $2 / 20$ & $10 \%$ & $2 / 5$ & $40 \%$ \\
\hline Jlka membeli Ayam, dan Daging, akan membeli Telur & 2 & $2 / 20$ & $10 \%$ & $2 / 5$ & $40 \%$ \\
\hline $\begin{array}{l}\text { Jika membeli Ayam dan Tomat, akan membeli Cabe } \\
\text { Merah }\end{array}$ & 4 & $4 / 20$ & $20 \%$ & $4 / 5$ & $80 \%$ \\
\hline Jika membeli Ayam dan Tomat, akan membeli Telur & 2 & $2 / 20$ & $10 \%$ & $2 / 5$ & $40 \%$ \\
\hline $\begin{array}{l}\text { Jika membeli Ayam dan Cabe Merah, akan membeli } \\
\qquad \text { Telur }\end{array}$ & 4 & $4 / 20$ & $20 \%$ & $4 / 6$ & $66,7 \%$ \\
\hline
\end{tabular}

Berikutnya dibuatlah kombinasi 4 itemset berikut hitungan support dan confidencenya seperti dalam Tabel 8.

Tabel 8. Pola Kombinasi 4 itemset

\begin{tabular}{|c|c|c|c|c|c|}
\hline Pola Kombinasi 4 itemset & Jumlah & \multicolumn{2}{|c|}{ Support } & \multicolumn{2}{c|}{ Confidence } \\
\hline Jika membeli Ayam, Daging, Tomat akan membeli Cabe Merah & 2 & $2 / 20$ & $10 \%$ & $2 / 2$ & $100 \%$ \\
\hline Jlka membeli Ayam, Daging, Tomat, akan membeli Telur & 0 & 0 & $0 \%$ & 0 & $0 \%$ \\
\hline Jika membeli Ayam, Tomat,Cabe Merah, akan membeli Telur & 1 & $1 / 20$ & $5 \%$ & $1 / 2$ & $50 \%$ \\
\hline Jika membeli Ayam, Daging, Cabe Merah, akan membeli Telur & 1 & $1 / 20$ & $5 \%$ & $1 / 3$ & $33.3 \%$ \\
\hline
\end{tabular}


Ditetapkan nilai confidence minimal adalah $50 \%$, maka yang terpilih berikut aturan asosiasi final terurut berdasarkan support $\mathrm{x}$ confidence adalah sebagaimana tertulis dalam Tabel 9.

Tabel 9. Aturan Asosiasi Final

\begin{tabular}{|c|c|c|c|}
\hline ATURAN & Support & Confidence & $\begin{array}{c}\text { Support x } \\
\text { Confidence }\end{array}$ \\
\hline $\begin{array}{l}\text { Jika membeli Ayam dan Tomat, maka akan membeli } \\
\text { Cabe Merah }\end{array}$ & $20 \%$ & $80 \%$ & $16 \%$ \\
\hline $\begin{array}{c}\text { Jika membeli Ayam dan Cabe Merah,maka akan } \\
\text { membeli Telur }\end{array}$ & $20 \%$ & $66.7 \%$ & $13.34 \%$ \\
\hline $\begin{array}{l}\text { Jika membeli Ayam, Daging, Tomat, maka akan } \\
\text { membeli Cabe Merah }\end{array}$ & $10 \%$ & $100 \%$ & $10 \%$ \\
\hline $\begin{array}{c}\text { Jika membeli Ayam, Tomat, Cabe Merah,maka akan } \\
\text { membeli Telur }\end{array}$ & $5 \%$ & $50 \%$ & $2.5 \%$ \\
\hline
\end{tabular}

Dari table di atas kemudian dapat diambil nilai prosentase terbanyak yaitu kombinasi Ayam, Cabe Merah, Telur. Sehingga manajemen akan memutuskan untuk membuat promosi bagi ketiga produk tersebut.

Mengenai berapa jumlah yang harus disediakan, harus melihat trend penjualan dalam kurun waktu tertentu. Misal ditetapkan dalam kurun 3 minggu terakhir untuk segmen konsumen end user. Kemudian dicari rata rata per minggunya. Lalu jumlah order ditentukan dengan memperhatikan rencana kenaikan penjualan di periode promosi nantinya. Misal ditentukan rencana kenaikan penjualan adalah $15 \%$, maka perhitungan seperti pada Tabel 10.

Tabel 10. Sales Trend dan Quantity Forecasting

\begin{tabular}{|c|c|c|c|c|c|}
\hline Produk & Sales (W1) & Sales (W2) & Sales (W3) & $\begin{array}{c}\text { Rata-rata } \\
\text { Sales }\end{array}$ & Quantity \\
\hline Ayam & 120 & 80 & 145 & 115 & 132.25 \\
\hline Cabe Merah & 50 & 60 & 44 & 154 & 177 \\
\hline Telur & 200 & 230 & 245 & 225 & 258.8 \\
\hline
\end{tabular}

Keterangan:

Quantity diperoleh dengan rumus : (15\% x Quantity ) + Quantity

\section{KESIMPULAN}

Berdasarkan data transaksi yang ada dalam kurun waktu tertentu, dan diimplementasikan ke dalam urutan teknik Algoritma Apriori, diperoleh kombinasi produk yang sering muncul dalam transaksi. Kombinasi produk inilah yang nantinya akan dipilih untuk dilakukan pemesanan lebih banyak dan diberikan diskon khusus untuk pelanggan. Setelah produk yang akan dipromosikan terpilih, selanjutnya menentukan jumlah order menggunakan sales trend dan sales forecasting berdasarkan kebijakan manajemen. Dapat disimpulkan bahwa teknik data mining dengan algoritma Apriori dapat diimplementasikan pada pemilihan produk yang akan dipromosikan, terutama pada perusahaan retail. 


\section{DAFTAR PUSTAKA}

Sujana, A.ST, 2012, Manajemen Minimarket, Raih Asa Sukses, Penebar Swadaya Group Ma'aruf, H, 2005, Pemasaran Ritel , PT Gramedia Pustaka Utama

Kusrini dan Luthfi, Emha Taufiq, 2009, Algoritma Data Mining, Penerbit Andi, Yogyakarta

Triyono, Sigit, 2006, Sukses Terpadu Bisnis Ritel Dari Merchandising sampai Shrinkage, PT Gramedia, Jakarta

Fibrani, Charitas, 2013, Algoritma Apriori, [online] http://charitasfibriani.files.wordpres s.com/2012/10/apriori.docx (diunduh tanggal 28 Agustus 2013) 